\title{
INTEGRASI IMTAQ DAN IPTEK DALAM MATA KULIAH ILMU KEALAMAN DASAR (IKD/ IAD)
}

\author{
Oleh: Milya Sari*
}

\begin{abstract}
Studying science and technology should not lead Moslems to atheism. Conversely, the more Moslems study science and technology, they more they realize the existence of "the All Controller" of the universe. In fact, Islam encourages its believers to seek for both science and technology based knowledge (aqliyah) and faith based ones (naqliyab). The improvement on faith (imtaq) can well realized through the mastery on science and technology. These two fields are not standing alone or even against one another. In fact, they should in a good integration. Such integration can be implemented through a subject called Ilmu Alamiah Dasar (Basic Science). Through learning and understanding the perfect creation of Allah, one will improve his/her faith and in turn get closer to Him.
\end{abstract}

Kata Kunci: integrasi, imtaq, iptek, ilmu kealaman dasar

\section{PENDAHULUAN}

$\mathrm{M}$ engapa dan untuk apa kita mempelajari alam? Marilah kita merujuk kembali kepada salah satu riwayat berikut ini, "Pada suatu hari di waktu subuh, sudah lama Bilal melakukan azan di masjid Madinah, namun Nabi belum juga keluar dari dalam gubuknya. Maka pergilah Bilal menjelang beliau, karena cemas kalau-kalau beliau dalam sakit. Maka masuklah Bilal ke dalam. Didapatnya Nabi sedang duduk termenung dan pada matanya terkesan bekas menangis. Lalu Bilal bertanya: Ya Utusan Allah, mengapa engkau menangis? Padahal kalau pun ada kesalahanmu, baik dahulu maupun nanti, akan diampuni oleh Tuhan." Lalu Nabi menjawab: Hai Bilal, tengah malam telah datang kepadaku Jibril membawa wahyu Tuhan yang berbunyi:
"Sesungguhnya dalam penciptaan langit dan bumi, dan silih bergantinya malam dan siang terdapat tanda-tanda bagi orang yang berakal, (yaitu) orang-orang yang mengingat Allah sambil berdiri atau duduk atau dalam keadaan berbaring dan mereka memikirkan tentang penciptaan langit dan bumi (seraya berkata), "Ya Tuhan kami, tiadalah Engkau menciptakan ini dengan sia-sia. Maha Suci Engkau, maka peliharalah kami dari siksa neraka. (Q.S. Ali Imran: 190-191).

"sengsaralah hai Bilal" ujar Nabi selanjutnya, bagi orang yang membaca akan ayat ini lalu tidak difikirkan maksudnya (Hamka,1987).

Siapakah diantara sekian banyak umat Islam yang mampu membaca, memahami, dan manafsirkan "ayat-ayat

* Penulis adalah Lektor dalam Mata Kuliah Pendidikan IPA Fakultas Tarbiyah IAIN Padang 
Allah" yang berkaitan dengan fenomena alam ini? Padahal dalam Al-Qur'an orang-orang seperti inilah yang dikatakan sebagai ulul albab yaitu kalangan yang beriman, bertaqwa dan mempunyai intelektual cemerlang sehingga mampu berkarya untuk kemaslahatan umat. Sekarang ini umat Islam seluruh dunia ketertinggalan dalam persoalan-persoalan Iptek. Beberapa alasan dikemukakan guna mencari sebab-sebab ketertinggalan tersebut. Salah satunya pendapat bahwa keterbelakangan komunitas Muslim dalam Iptek karena umat Islam lalai dalam memahami serta mengamalkan ajaran agamanya, sementara Islam sendiri menganjurkan umatnya untuk menguasai Iptek (Milya Sari, 2002).

Tantangan umat Islam masa kini adalah bagaimana caranya mencetak orang-orang yang beriman yang mempunyai kemampuan Iptek, dan sebaliknya yaitu ahli-ahli Iptek yang ber-Imtaq. Satu cara yang bisa dilakukan untuk mencapai hal tersebut ialah melalui pendidikan formal, khususnya perguruan tinggi, mengingat perguruan tinggi merupakan jenjang pendidikan yang paling kompeten dalam melahirkan sarjanasarjana keagamaan maupun sarjana Iptek. Dalam hal ini tidak memandang apakah itu Perguruan Tinggi Agama Islam (PTAI-IAIN/STAIN) atau Perguruan Tinggi Umum lainnya.

Bagaimana peluang PTAI menghadapi tangtangan tersebut? Sebetulnya PTAI sangat berpeluang mencetak orang-orang yang beriman yang mempunyai kemampuan Iptek, dan sebaliknya yaitu ahli-ahli Iptek yang ber-Imtaq. Masalahnya, sampai sejauh mana PTAI tersebut mampu memadukan kedua bidang tersebut. Untuk menyikapi hal ini, maka setiap kegiatan pendidikan di PTAI bertujuan agar output-nya dapat mengikuti pekembangan/tuntutan zaman tersebut. Tujuan ini akan gagal bila tidak memperhitungkan kedudukan Iptek da- lam kurikulum. Penempatan Iptek dalam kurikulum tanpa mengabaikan nilai-nilai agama akan memberi bekal anak-anak masa kini untuk hidup di masa datang (Milya Sari, 2004).

Syafrudin (1999) menemukan temuan, bahwa: "Kurang berhasilnya pembinaan integritas ilmu pengetahuan umum dan keagamaan di Lembaga Pendidikan Islam disebabkan oleh beberapa faktor, antara lain: kurikulum masih didisain secara terpisah-pisah; belum adanya model/pedoman kurikulum dan pembelajaran terpadu yang dapat menunjang pembentukan integrasi pengetahuan tersebut, disamping kemampuan guru dan sarana yang tidak memadai".

Upaya yang dilakukan pemerintah untuk mengatasi persoalan di atas antaranya diterbitkannya "Naskah Keterkaitan 10 Mata Pelajaran di SMU dengan Imtaq" (Depdikbud, 1996). Ini juga berlaku di madrasah. Dalam naskah tersebut setiap materi pelajaran iptek diberi materi landasan imtaq (al-Qur'an dan Hadist) yang dapat digunakan sebagai pedoman dan acuan bagi guru mata pelajaran umum dalam rangka integrasi. Begitu juga dengan guru agama Islam baik di madrasah maupun di sekolah umum. Mereka juga harus mampu mengajarkan agama (imtaq) yang terintegrasi dengan iptek.

Untuk mewujudkan obsesi di atas, mata kuliah yang diberikan di PTAI harus dipahami dalam satu kesatuan ilmu. Disamping itu, pendidikan agama ke depan harus mampu menjadikan agama sebagai landasan dalam mendalami disiplin ilmu-ilmu umum. Pendidikan agama mampu memberi makna lebih dalam mengenai maksud dan kegunaan ilmu yang dipelajari dalam kehidupannya. Inilah sebabnya dibutuhkan ilmu pengetahuan yang memuat uraian teologi; ilmu-ilmu tentang jagat raya, ilmu-ilmu tentang manusia dan bagaimana hubungan manusia dengan segala 
kemajuan ipteknya dengan lingkungan. Materi ini salah satunya dapat diperoleh pada mata kuliah Ilmu Kealaman Dasar (IAD).

\section{KEDUDUKAN DAN RUANG LING- KUP MATAKULIAH ILMU KE- ALAMAN DASAR DI PERGURUAN TINGGI}

Sebelum tahun 2000, mata kuliah di perguruan tinggi dikelompokkan atas Mata Kuliah Dasar Umum (MKDU), Mata Kuliah Dasar Keahlian (MKDK), Mata Kuliah Keahlian (MKK) dan Mata Kuliah Pilihan (MK-P), hal ini didasarkan keputusan Menteri Pendidikan dan Kebudayaan No. 0561U/94. Mata kuliah Ilmu Alamiah Dasar (IAD) termasuk dalam MKDU, merupakan matakuliah yang wajib diberikan pada mahasiswa bidang IPS.

Setelah tahun 2000, atas dasar keputusan Menteri Pendidikan Nasional No.232X/2000 tentang Pedoman Penyusunan Kurikulum Pendidikan Tinggi dan Penilaian Hasil Belajar Mahasiswa, menetapkan bahwa:

1. Kurikulum Inti merupakan bahan kajian dan pelajaran yang harus dicakup dalam satu program studi yang dirumuskan dalam kurikulum yang berlaku secara nasional

2. Kurikulum inti terdiri atas kelompok Mata Kuliah Pengembangan Kepribadian (MPK), Mata Kuliah Keahlian Berkarya (MKB), Mata Kuliah Keilmuan dan Ketrampilan (MKK), Mata Kuliah Perilaku Berkarya (MPB) dan Mata Kuliah Berkehidupan Bermasyarakat (MBB). Kelompok MBB, adalah kelompok bahan kajian dan pelajaran yang diperlukan seseorang untuk dapat memahami kaidah berkehidupan bermasyarakat sesuai dengan pilihan keahlian dalam berkarya.
Maka melalui Keputusan Dikjen Dikti No. 30/DIKT1/Kep/2003 ditetapkan tentang Rambu-Rambu Pelaksanaan (RRP) Kelompok Mata kuliah Berkehidupan Bermasyarakat (MBB) di Perguruan Tinggi memutuskan IAD termasuk dalam MBB dan wajib diprogramkan dalam setiap kurikulum inti program studi dengan bobot sekurang-kurangnya 2 (dua) sks. Selanjutnya melalui surat Keputusan Diden Dikti No. 44/DIKT1/Kep/2006 tentang RambuRambu Pelaksanaan Kelompok Matakuliah Berkehidupan Bermasyarakat (MBB) di Perguruan Tinggi mewajibkan IAD diprogramkandalam setiap kurikulum inti program studi dengan bobot sekurang-kurangnya 3 (tiga) sks.

Hakekatnya IAD bukanlah merupakan suatu disiplin ilmu, melainkan suatu pengetahuan tentang konsep-konsep dasar yang ada dalam ilmu Pengetahuan Alam dan Teknologi. Pelaksanaan perkuliahan IAD ditujukan untuk membantu para mahasiswa agar memiliki pandangan yang lebih luas dalam bidang Ilmu Pengetahuan Alam, serta mendekati persoalan pengetahuan alam dengan penalaran yang lebih komprehensif.

Sasaran perkuliahan IAD adalah agar mahasiswa yang mengikuti mata kuliah IAD dapat memperoleh dan memahami pengetahuan yang ada dan termasuk dalam bidang IPA dan Teknologi, serta dapat menanggapi dan menghargai pengetahuan tersebut. Diharapkan sesudah mengikuti mata kuliah IAD ini, dapat membuat para mahasiswa menyadari bahwa IPA dan teknologi ternyata merupakan pengetahuan yang memperkaya cakrawala wawasannya. Dan yang terpenting mereka menyadari kalau antara IPA dengan agama tidak pernah ada pemisahan.

Ruang lingkup mata kuliah IAD mencakup bahasan: 
1). Pengantar IAD; Hakikat dan ruang lingkup IAD sebagai bagian dari $\mathrm{MBB}$,

2). Alam Pikiran Manusia dan Perkembangannya; Hakikat manusia dan sifat keingintahuannya, Perkembangan fisik, sifat dan pikiran manusia, dan Sejarah pengetahuan manusia,

3). Perkembangan dan Pengembangan Ilmu pengetahuan Alam; Metode ilmiah sebagai dasar IPA, Perkembangan IPA, dan Ruang lingkup IPA dan pengembangannya,

4). Bumi dalam Alam Semesta; Pembentukan alam semesta dan tata surya, Bumi sebagai planet, Struktur bumi, Pembentukan Benua dan Samudra,

5). Keanekaragaman Makhluk Hidup dan Penyebarannya; Biosfer dan makhluk hidup, Asal mula kehidupan di bumi, Keanekaragaman makhluk hidup, Persebaran dan sejarah perkembangan makhluk hidup,

6). Makhluk Hidup dalam Ekosistem Alami; Populasi dan komunitas makhluk hidup, Berbagai bentuk ekosistern alam, Aliran energi dan materi dalam ekosistern alam, Macam-macam bentuk pola kehidupan,

7). Sumberdaya Alam dan Lingkungan; Klasifikasi sumberdaya alam dan lingkungan hidup, Konsep-konsep pengelolaan sumberdaya alam, Masalah kependudukan dan lingkungan hidup, Prinsip dan usaha pelestarian sumberdaya alam dan lingkungan hidup,

8). Ilmu Pengetahuan Alam dan Teknologi bagi Kehidupan Manusia; IPA sebagai dasar pengembangan teknologi, Sejarah peradaban manusia dan perkembangan teknologi, Manfaat dan dampak IPA dan Teknologi terhadap kehidupan sosial, IPA dan Teknologi masa depan,

9). Beberapa Perkembangan Teknologi Penting; Bioteknologi, Teknologi
Informasi. Dan Teknologi kearifan lokal,

10).Isu Lingkungan; Isu lingkungan global, Isu lingkungan nasional, Isu lingkungan lokal, Studi kasus.

\section{INTEGRITAS IMTAQ DAN IPTEK DALAM MATA KULIAH ILMU KEALAMAN DASAR}

Istilah 'iptek' dan 'imtaq' merupakan dua istilah yang merupakan singkatan dari 'ilmu pengetahuan dan teknologi' dan 'iman dan taqwa'. Istilah iptek merupakan perpaduan antara ilmu pengetahuan (sains) dan teknologi. Sains dan teknologi merupakan dua hal yang tidak terpisahkan, sains merupakan sumber teknologi dan teknologi merupakan aplikasi sains. Sains dapat diartikan sebagai himpunan rasional kolektif insan, tentang alam yang diperoleh melalui konsensus para pakar. Sedangkan teknologi adalah sebagai himpunan pengetahuan terapan manusia tentang prosesproses pemanfaatan alam yang diperoleh dari penerapan sains, dalam kegiatan yang produktis ekonomis (Ahmad Baiquni, 1997).

Istilah imtaq merupakan gambaran karakteristik nilai-nilai keagamaan (keislaman) yang harus dimiliki oleh setiap muslim. Imtaq merupakan urusan yang sarat dengan nilai, kepercayaan, pemahaman, sikap, perasaan dan perilaku yang bersumber dari al-Qur'an dan Hadist (Ahmad Sanusi dalam Syaifuddin, 2006). Selanjutnya dikatakan, ajaran Islam bukan semata-mata aspek teologi tetapi mencakup seluruh aspek kehidupan termasuk ilmu pengetahuan umum (selain agama), meskipun dilihat dari proses lahirnya sebagian bersifat ijtihad/hasil pemikiran manusia.

Islam tidak memandang ilmu agama (imtaq) dan ilmu umum (iptek) terpisah, karena keduanya berasal dari sumber yang satu, yaitu Allah swt. 
Pengetahuan dalam bentuk imtaq adalah pengetahuan yang bersumber langsung dari Allah swt, dalam bentuk wahyu yang diturunkan melalui Nabi $\mathrm{Mu}-$ hammad saw sebagai rasulnya. Sedangkan pengetahuan dalam bentuk iptek, pada dasarnya juga berasal dari Allah, yang didapat oleh manusia melalui alam, akal/nalar manusia yang diciptakan oleh Allah swt.

Selama ini pembinaan Imtaq siswa di sekolah dianggap sebagai tugas pendidikan agama. Bagi siswa yang beragama Islam tugas itu hanya menjadi tanggungjawab guru Pendidikan Agama Islam (PAI) saja. Mempercayakan pendidikan pembinaan Imtaq siswa hanya kepada satu mata pelajaran mengandung kelemahan. Baik dari segi hakikat pendidikan nasional sebagai suatu sistem maupun hakekat proses pendidikan yang ideal, yaitu yang mampu mengembangkan semua dimensi kepribadian peserta didik secara utuh seperti yang dinyatakan dalam GBHN dan UU Sisdiknas (Dedi Supriadi, 2004).

Integrasi materi Imtaq dan Iptek ini salah satunya bisa pada mata pelajaran MIPA (Matematika dan Ilmu Pengetahuan Alam). Perlu dicatat apa yang dikemukakan oleh Prof. Wardiman Djojonegoro cit Dedi Supriadi (2004) dalam pengukuhannya sebagai guru besar di Universitas Padjadjaran, Bandung, pada tahun 1994 bahwa pendidikan MIPA mengandung tiga aspek. Pertama, berkenaan dengan substansi ke-MIPA-an (science education). Melalui pendidikan MIPA peserta didik diarahkan untuk menguasai dalil-dalil, teori-teori, generalisasi-generalisasi, konsep-konsep, dan prinsip-prinsip MIPA untuk kemudian diterapkan dalam pemecahan masalah keilmuan. Kedua, MIPA merupakan alat (means) pendidikan yang lebih luas, yang dikenal dengan education through science. Melalui MIPA, logika berpikir peserta didik dikembangkan sehingga lebih tertib, lugas, dan sistematis. Ketiga, aspek nilai moral dan etik yang terkandung dalam pendidikan MIPA.

Pada aspek ketiga ini, melalui MIPA peserta didik dapat lebih mencintai lingkungan, sadar akan keuntungan MIPA bagi kehidupan manusia, dan sadar pula akan implikasi dari penerapan MIPA terhadap kehidupan manusia. Jika disalahgunakan untuk tujuan-tujuan yang destruktif seperti pembuatan bom nuklir, eugenetika aktif (catatan: contohnya adalah kloning), eksploitasi sumberdaya alam yang melebihi batas, akan menimbulkan kerusakan. Disamping itu, peserta didik dapat lebih memahami betapa agung dan perkasanya Allah yang menciptakan alam semesta ini dalam keadaan tertib, tidak kacau. Dalam al-Qur'an, misalnya, banyak kita temukan amsal-amsal yang baik secara eksplisit maupun implisit menjelaskan bagaimana alam semesta bersama isinya ini tunduk kepada hukum-hukum Allah, mulai dari perilaku lebah sampai kepada orbit planet di tata surya. Oleh sebab, itu, jika dikembalikan kepada dasarnya, MIPA sesungguhnya merupakan upaya untuk memahami hukum-hukum Allah (sunnatullah) yang juga disebut "hukum alam".

Demikian juga dengan materimateri lain yang yang dipelajari dalam mata kuliah IAD ini. Pembahasan materinya disajikan secara terpadu antara konsep IPA dengan ayat-ayat kauniyah yang berhubungan dengan materi tersebut sehingga mereka menemukan pesan-pesan ketuhanan (uluhiyah) yang terkandung di dalamnya. Banyak sekali ayat Al-Qur'an (ayat kauniyah) yang berhubungan dengan bidang IPA (Astronomi, biologi, fisika dan kimia) dan penafsiran ayat-ayat tersebut membutuhkan iptek. Ini besar sekali pengaruhnya terhadap pembinaan imtaq peserta didik, karena dengan iptek membuktikan kalau Al-Qur'an tersebut benar-benar firman 
dari Allah SWT. Dengan demikian, dengan mempelajari IPA bisa menambah nilai ketaqwaan kepada Sang Pencipta, karena materi IAD memperlihatkan keteraturan alam yang merupakan bukti ke Esaan Allah.

Zainuddin Sardar (1996) mengemukakan tiga bentuk/cara mengintegrasi atau pemaduan iptek dan imtaq ini. 1). Dengan cara mengkonsultasikan konsep atau teori-teori iptek dengan paradigma dan prinsip-prinsip sains islami guna melahirkan sains yang islami; 2). Dengan cara menghubungkan teori dan konsep-konsep iptek dengan teori dan konsep imtaq; 3) dengan cara melakukan hubungan timbal balik dua arah.

Penelitian yang dilakukan oleh Ara Hidayat (2002) menunjukkan bahwa; siswa lebih tertarik mempelajari IPA apabila pembahasan materinya disajikan secara terpadu antara konsep kehidupan alam (kauniyah) dengan pesan-pesan ketuhanan (uluhiyah), sehingga mereka menyadari tidak ada keterpisahan di antara keduanya dalam kehidupan sehari-hari mereka. Bagaimana seharusnya hidup berdampingan antara manusia dengan lingkungannya merupakan bagian dari materi biologi dan ekologi. Fenomena hidup secara mendasar dipelajari secara deskriptif berdasarkan pengamatan adalah lingkup dan cakupan Biologi yang amat penting dipelajari terhadap suatu perlakuan untuk menjaga keseimbangan antara makhluk hidup di lingkungannya.

Salah satu materi dalam IAD yang banyak mengintegrasikan konsep iptek dan imtaq adalah biologi. Materi ini membahas; sel, asal mula mahkluk hidup, ekologi dan bioteknologi. Keteraturan susunan sel pada mahkluk hidup mulai dari tingkat uniseluler hingga multi seluler dengan kerumitan sistem organnya akan membuat orang sadar ada yang "menciptakan". Kerumitan dan kesempurnaan penciptaan ini tidak bisa di kalahkan oleh teknologi muhktahir sekalipun.

Harun Yahya (2000) mengungkapkan; Manusia adalah salah satu makhluk hidup yang terhebat dan tercanggih. Sistem tubuhnya paling menakjubkan di alam, dibentuk Allah dengan proporsi yang pas. Tubuh manusia terdiri atas sejumlah daging dan tulang yang berbobot kurang lebih 60-70 kg. Sebagaimana diketahui, daging adalah salah satu material paling rentan di alam. Jika dibiarkan di tempat terbuka, daging akan membusuk dalam beberapa jam, dan setelah beberapa hari dikerubungi tempayak dan mulai berbau busuk tak tertahankan. Zat yang sangat lemah ini membentuk bagian terbesar tubuh manusia. Akan tetapi, ia terpelihara tanpa rusak atau membusuk selama kurang lebih 70-80 tahun, dengan adanya peredaran darah yang memberinya makanan dan kulit yang melindunginya dari bakteri luar.

Berbagai mekanisme menakjubkan dalam tubuh manusia umumnya berfungsi tanpa sepengetahuan atau kesadarannya manusia. Detak jantung, fungsi hati, peremajaan kulit seluruhnya terjadi di luar pengetahuan langsung kita. Demikian pula halnya dengan ratusan organ manusia lainnya yang tidak diuraikan di sini. Bahkan kita tidak menyadari bahwa ginjal menyaring darah, lambung mencerna makanan yang di makan, gerakan usus, atau kerja paruparu yang sempurna sehingga membantu bernapas. Jadi, bagaimana mekanisme sempurna ini ada pada tubuh manusia? Pertanyaan ini tidak terlalu sulit dijawab bagi manusia beriman, yang memiliki pengetahuan untuk memahami dan merasakan bahwa tubuhnya telah "diciptakan".

"Kami telah menciptakan kamu, maka mengapa kamu tidak membenarkan? Maka, terangkanlah kepadaku tentang nutfah yang kamu 
pancarkan? Kamukah yang menciptakannya, atau Kamikah yang menciptakannya? Kami telah menentukan kematian di antara kamu, Kami sekali-kali tidak dapat dihalalkan untuk menggantikan kamu dengan orang-orang yang seperti kamu dan menciptakan kamu kelak dalam keadaan yang tidak kamu ketahui. (Surat Al Waaqi'ah: 57-61).

Materi IAD lainya yang mengintegrasikan iptek dan imtaq adalah Ilmu Pengetahuan Bumi dan Antariksa (IPBA). Materinya berhubungan dengan penciptaan Alam Semesta. Ketika menjelajahi alam semesta, ditemukan banyak contoh keteraturan. Dunia yang di tempati ini hanyalah salah satunya. Dengan segala keistimewaan yang ada padanya, bumi diciptakan dengan keseimbangan yang luar biasa stabil, yang membuatnya cocok bagi berlangsungnya kehidupan makhluk hidup.

Kalau dibandingkan dengan planet lain, semakin jelas bahwa bumi secara khusus dirancang bagi manusia. Air, misalnya, adalah senyawa yang sangat sulit ditemukan di planet lain. Dalam tata surya, air berwujud cair hanya ditemukan di bumi. Terlebih lagi, $70 \%$ permukaan bumi tertutup oleh air. Jutaan jenis makhluk hidup hidup di air. Pembekuan air, kapasitas air untuk menarik dan menyimpan panas, adanya badan air berukuran besar berbentuk lautan, dan bahkan penyaluran panas yang melintasi bumi adalah karakteristik yang hanya dimiliki oleh bumi. Tidak ada planet lain yang memiliki sirkulasi badan cair yang konstan seperti yang terdapat di bumi. Kecepatan rotasi bumi pada sumbunya merupakan kecepatan yang paling sesuai bagi makhluk hidup. Planet-planet lain dalam tata surya pun mengalami siang dan malam. Karena perbedaan waktu di planet lain jauh lebih besar dibandingkan dengan di bumi, perbedaan antara suhu siang dan malam pun sangat tinggi.
Hebatnya aktivitas angin di atmosfer planet lain tidak di temukan di bumi ini, suatu keistimewaan berkat rotasi planet bumi yang seimbang (Harun Yahya, 2000).

Selanjutnya, persoalan mengenai bagaimana alam semesta yang tanpa cacat ini mula-mula terbentuk, ke mana tujuannya, dan bagaimana cara kerja hukum-hukum yang menjaga keteraturan dan keseimbangan, sejak dulu merupakan topik yang menarik. Awal abad ke21, melalui sejumlah besar percobaan, pengamatan, dan perhitungan, fisika modern telah mencapai kesimpulan bahwa alam semesta memiliki awal, bahwa alam diciptakan dari ketiadaan dan dimulai oleh suatu ledakan besar. Selain itu, dinyatakan bahwa alam semesta tidaklah stabil atau konstan, tetapi senantiasa bergerak, berubah, dan memuai. Saat ini, fakta-fakta tersebut telah diakui oleh dunia ilmu pengetahuan. Sekarang, marilah di lihat bagaimana fakta-fakta yang sangat penting ini dijelaskan oleh ilmu pengetahuan.

Pada tahun 1929, di observatorium Mount Wilson di California, seorang astronom Amerika bernama Edwin Hubble membuat salah satu temuan terpenting dalam sejarah astronomi. Ketika tengah mengamati bintang dengan teleskop raksasa, dia menemukan bahwa bintang-bintang tersebut senantiasa bergerak menjauh. Bintang dan galaksi bukan hanya bergerak menjauh, namun juga saling menjauhi. Satu-satunya kesimpulan yang dapat dibuat tentang alam semesta yang semua isinya bergerak saling menjauhi adalah bahwa alam semesta itu senantiasa memuai. Agar lebih mudah dimengerti, bayangkan alam semesta seperti permukaan balon yang tengah ditiup. Sama seperti titik-titik pada permukaan balon akan saling menjauhi karena balonnya mengembang, bendabenda di angkasa saling menjauhi karena alam semesta terus memuai. 
Jadi, apakah pentingnya fakta pemuaian alam semesta ini terhadap keberadaan alam semesta? Pemuaian alam semesta secara tidak langsung menyatakan bahwa alam semesta bermula dari satu titik tunggal. Hasil perhitungan menunjukkan bahwa "satu titik tunggal" yang mengandung semua materi alam semesta ini pastilah memiliki "volume nol" dan "kepadatan tak terbatas". Alam semesta tercipta akibat meledaknya titik tunggal yang memiliki volume nol tersebut. Ledakan hebat yang menandakan awal terbentuknya alam semesta ini dinamakan Ledakan Besar (Big Bang), dan teori ini dinamai mengikuti nama ledakan tersebut. Fakta ini, yang baru ditemukan oleh fisika modern pada akhir abad ini, telah diberitakan Al Quran empat belas abad yang lalu:

"Dia Pencipta langit dan bumi." (QS. Al An'am:101)

"Dan apakah orang-orang kafir itu tidak mengetahui bahwasanya langit dan bumi itu keduanya dahulu adalah sesuatu yang padu, Kemudian Kami pisahkan antara keduanya. Dan dari air Kami jadikan segala sesuatu yang hidup. Maka mengapakah mereka tidak juga beriman (Al Anbiya: 30).

Jika dibandingkan pernyataan pada ayat di atas dengan teori Ledakan Besar, terlihat kesamaan yang sangat jelas. Namun, teori ini baru diperkenalkan sebagai teori ilmiah pada abad ke-20. Pemuaian alam semesta merupakan salah satu bukti terpenting bahwa alam semesta diciptakan dari ketiadaan. Meskipun fakta di atas baru ditemukan pada abad ke-20, Allah telah memberitahukan kenyataan ini dalam Al Quran 1.400 tahun yang lalu:

"Dan langit itu Kami bangun dengan kekuasaan (Kami) dan sesungguhnya Kami benar-benar berkuasa." (Surat Adz-Dzariyat:47)
Pada tahun 1948, George Gamov mengemukakan gagasan lain mengenai teori Ledakan Besar. Dia menyatakan bahwa setelah terbentuknya alam semesta dari ledakan hebat, di alam semesta seharusnya terdapat surplus radiasi, yang tersisa dari ledakan tersebut. Lebih dari itu, radiasi ini seharusnya tersebar merata di seluruh alam semesta. Bukti "yang seharusnya ada" ini segera ditemukan. Pada tahun 1965, dua orang peneliti bernama Arno Penzias dan Robert Wilson, menemukan gelombang ini secara kebetulan. Radiasi yang disebut "radiasi latar belakang" ini tampaknya tidak memancar dari sumber tertentu, tetapi meliputi seluruh ruang angkasa. Dengan demikian, dapat dipahami bahwa gelombang panas yang memancar secara seragam dari segala arah di angkasa ini merupakan sisa dari tahapan awal Ledakan Besar. Penzias dan Wilson dianugerahi Hadiah Nobel untuk temuan ini.

Semua bukti kuat ini memaksa komunitas ilmiah untuk menerima teori Ledakan Besar. Model ini merupakan titik terakhir yang dicapai oleh para ahli kosmologi berkaitan dengan awal mula dan pembentukan alam semesta. Banyak ilmuwan, yang tidak secara buta terkondisikan menjadi ateis, telah mengakui keberadaan Yang Maha Pencipta dalam penciptaan alam semesta. Sang Pencipta pastilah Dia yang menciptakan zat dan ruang/waktu, tetapi Dia tidak bergantung pada ciptaannya. Seorang ahli astrofisika terkenal bernama Hugh Ross mengatakan: Jika waktu memiliki awal yang bersamaan dengan alam semesta, seperti yang dikatakan teoremaruang, maka penyebab alam semesta pastilah suatu wujud yang bekerja dalam dimensi waktu yang benar-benar independen dari, dan telah ada sebelum, dimensi waktu kosmos.

Kesimpulan ini sangat penting bagi pemahaman kita tentang siapakah 
Tuhan, dan siapa atau apakah yang bukan Tuhan. Hal ini mengajarkan bahwa Tuhan bukanlah alam semesta itu sendiri, dan Tuhan tidak berada di dalamnya. Allah memberi tahu bukti-bukti ilmiah ini dalam Kitab-Nya, yang Dia turunkan kepada manusia empat belas abad lalu untuk menunjukkan keberadaan-Nya.

Tanda-tanda Allah di langit dan bumi sangat jelas dan tak dapat disangkal. Allah-lah Pencipta langit, bumi dan segala sesuatu di antara keduanya. Tanda-tanda Keberadaan-Nya meliputi seluruh jagad raya. Dengan mempelajari alam dan menemukan kesempurnaan yang luar biasa ini diharapkan keimanan kita semakin bertambah dan meningkat. Sehingga seperti dikatakan di awal tadi bahwa mata kuliah IAD merupakan satu contoh mata kuliah yang menggabungkan (terintegrasi) aspek iptek dan imtaq.

\section{PENTINGNYA PENGUASAAN ILMU PENGETAHUAN DAN TEKNOLOGI BAGI LULUSAN PTA I}

Mengapa dan untuk apa dipelajari alam? Pertama, karena sejak manusia dilahirkan ia memiliki sifat ingin tahu. Sifat ingin tahu mendorong seseorang mempelajari ilmu alam. Bukanlah Allah telah Menciptakan alam semesta itu untuk kepentingan umat manusia? Allah mentakdirkan manusia menjadi makhluk yang paling mulia. Ia telah menyerahkan alam yang serba indah dan teratur itu kepada manusia agar suka menyelidiki semua rahasia-rahasianya dan pandai memanfaatkannya untuk kepentingan manusia sendiri.

Kedua, karena pada dasarnya manusia ingin hidup enak dan serba mudah. Ia selalu mencari akal bagaimana memanfaatkan semua benda-benda, makhluk-mahkluk dan gejala-gejala alam di sekitarnya untuk memudahkan pekerjaannya sehari-hari. Bukankah nenek moyang dulu sudah mengenal roda dan poros, pengungkit dan alat-alat mesin lain yang sederhana? Air sungai, air terjun dan sebagainya telah mereka manfaatkan untuk sekedar meringankan pekerjaannya (Tim Penulisan Buku Sains, 1981).

Bagaimana cara mempelajari ilmu alam? Terlebih dahulu yang harus diketahui, bagaimana cara ahli-ahli ilmu alam itu bekerja. Dengan bekal sifat ingin tahunnya yang kuat mereka melakukan pengamatan-pengamatan yang teliti. Dari hasil pengamatan-pengamatan itu disusunlah hipotesa-hipotesa atau dugaan-dugaan sementara. Kemudian dilakukan percobaan-percobaan untuk memeriksa apakah hipotesa itu baik atau tidak. Berdasarkan hipotesa yang baik itu maka disusunlah suatu teori. Demikianlah para ahli ilmu alam itu berkerja. Metoda yang dipakai itu dinamakan metoda ilmiah. Sudah barang tentu, metoda ilmiah tidak selalu mengikuti urutan langkah-langkah yang telah dikemukakan tadi.

Apa perlunya penguasaan iptek bagi lulusan PTAI? Yusuf Qardawi (2006) menyatakan: Sesungguhnya ilmu pengetahuan mesti didahulukan atas amal perbuatan, karena ilmu pengetahuanlah yang mampu membedakan antara yang haq dan yang bathil dalam keyakinan umat manusia, antara yang benar dan yang salah di dalam perkataan mereka; antara perbuatan-perbuatan yang disunatkan dan yang bid'ah dalam ibadah; antara yang benar dan yang tidak benar di dalam melakukan muamalah; antara tindakan yang halal dan tindakan yang haram; antara yang terpuji dan yang hina di dalam akhlak manusia; antara ukuran yang diterima dan ukuran yang ditolak; antara perbuatan dan perkataan yang bisa diterima dan yang tidak dapat diterima. Dengan ilmu pengetahuan dapat diketahui apa 
yang mesti didahulukan dan apa yang harus diakhirkan.

Oleh karena itu, Imam Hasan alBashri dalam Yusuf Qardawi (2006) memperingatkan "Orang yang beramal tetapi tidak disertai dengan ilmu pengetahuan tentang itu, bagaikan orang yang melangkahkan kaki tetapi tidak meniti jalan yang benar. Orang yang melakukan sesuatu tetapi tidak memiliki pengetahuan tentang sesuatu itu, maka dia akan membuat kerusakan yang lebih banyak daripada perbaikan yang dilakukan. Carilah ilmu selama ia tidak mengganggu ibadah yang engkau lakukan. Dan beribadahlah selama ibadah itu tidak mengganggu pencarian ilmu pengetahuan.

Seseorang ulama tidak boleh memberikan fatwa kepada manusia kecuali dia seorang yang betul-betul ahli dalam bidangnya, dan memahami ajaran agamanya. Jika tidak, maka dia akan mengharamkan yang halal dan menghalalkan hal-hal yang haram. Setiap juru dakwah (da'i) harus melandasi dakwahnya dengan hujjah yang nyata. Artinya, d a'wah yang dilakukan olehnya mesti jelas, berdasarkan kepada hujjah-hujjah yang jelas pula.

Ada banyak materi dalam mata kuliah IAD yang membuka cakrawala mengapa sesuatu itu haram dan halal. Misalnya tentang bayi tabung, mengapa ulama sepakat hal ini dibolehkan dan dalam batasan yang bagaimana? Seseorang akan bisa mengatakan halal dan haram jika mempunyai ilmu tentang hal tersebut. Begitu juga dengan banyaknya masalah lingkungan yang terjadi disekitar kita. Para da'i dan guru agama pun bisa berperan penting dalam usaha menjaga lingkungan hidup. Tapi peran tersebut akan terlaksana dengan baik jika mereka punya ilmu tentang bagaimana "sunatullah" yang punya hubungan sebab dan akibat itu terjadi di alam.

Tantangan yang dihadapi oleh lulusan PTAI adalah semakin banyaknya lembaga-lembaga pendidikan yang memadukan iptek dengan imtaq. Filosofi lembaga pendidikan ini adalah sami'ul wal mutakamil. Yaitu memadukan antara ayat-ayat kauliah/naqliah (al-Qur'an/ Hadist) dan kauniyah (fenomena alam). Dengan konsep pendidikan seperti itu, dalam operasionalnya, ketika peserta didik mempelajari Ilmu Pengetahuan Alam (IPA) misalnya, sudah mendapat dasar pemahaman terhadap ayat-ayat al-Qur'an. Seperti fenomena alam tentang air dan udara, Allah menyinggungnya dalam kitab suci. Hasil yang diharapkan adalah, peserta didik tidak semata-mata mempelajari IPA, tapi sekaligus dipupuk keimanannya kepada Allah. (Asep Nur Zaman. 2003).

Kecendrungan yang terjadi sekarang pun orang tua lebih banyak menyekolahkan anak-anaknya di lembaga pendidikan terpadu ini. Sekarang orang mulai sadar bahwa bersekolah itu tidak hanya mengembangkan potensi akal, tetapi juga mengembangkan potensi spiritual. Hal ini harus menjadi tantangan bagi PTAI untuk menghasilkan lulusan yang tidak hanya menguasai imtaq tapi juga iptek. Bagaimana menghasilkan guru agama islam yang juga paham terhadap iptek.

Guru agama juga harus mampu mengajarkan agama melalui pendekatan iptek. Pemahaman peserta didik terhadap materi agama sebaiknya melalui pemahaman mereka terhadap alam sekitar dan diri mereka sendiri. Misalnya, mengajarkan tentang Maha Penciptanya Allah, guru agama harus mampu mengemukakan bukti ilmiah terhadap Maha Penciptanya Allah tersebut. Mengapa Islam mengharamkan beberapa jenis hewan untuk dimakan? Untuk apa kita bersuci sebelum salat, apa pentingnya bersuci tersebut? Mengapa harus menjaga lingkungan? Apa untung lingkungan tersebut dijaga, bukankah kita sebagai kalifah Allah di muka bumi, maka segala isi 
bumi tersebut memang diciptakan untuk di pakai oleh manusia dalam kehidupan sehari-harinya? Semua hal ini akan mudah dipahami jika diajarkan dengan penjelasan dan bukti-bukti ilmiah (iptek). Itulah diantara banyak alasan mengapa mahasiswa PTAI perlu mendapatkan materi perkuliahan ini.

Mudah-mudahan dengan materi kuliah yang mengintegrasikan iptek dan imtaq ini lulusan PTAI kedepan menjadi lebih berkualitas. Sehingga tidak ada lagi tudingan miring yang diberikan kepada lembaga pendidikan yang berlabelkan Islam. Guru-guru sekolah Islam atau guru agama Islam sering dituding amatiran dan gatek (gagap teknologi) dengan peserta didik lebih banyak berstatus "anak buangan". Dengan kualitas lulusan yang semakin baik, bisa membentuk umat yang memperbaiki dunia, Amin.

\section{KESIMPULAN}

Islam tidak memandang ilmu agama (imtaq) dan ilmu umum (iptek) terpisah, karena keduanya berasal dari

\section{DAFTAR RUJUKAN}

Baiquni Ahmad, 1997. Al-Qur'an dan Ilmu Pengetahuan Kealaman. Dana Bhakti Primayasa. Yogyakarta.

Ara Hidayat. 2002. Peran Guru IPA Biologi dalam Menbudidayakan Hidup Sehat, Pembelajaran Terpadu untuk Menunjang Pendidikan Kewarganegaraan. Abstrak Thesis Program Studi Pendidikan Umum, PPs UPI lulusan tahun 2002. http://www.upi.org. Diakses Desember 2007.

Asep Nur Zaman. 2003. Pendidikan Islam Keluar dari Suasana Kolot. Koran Republika. Senin 6 Januari 2003. sumber yang satu, yaitu Allah swt. Semakin seseorang itu mendalami Iptek, makin sadarlah ia akan adanya suatu ketertiban di dalam alam raya ini. Di mana-mana ada aturan: hukum-hukum alam ciptaan Tuhan (sunnahtullah) yang tertib dan tak dapat dibantah kebenarannya. Materi IAD disajikan secara terpadu antara konsep iptek dan imtaq sehingga peserta didik menemukan pesan-pesan ketuhanan (uluhiyah) yang terkandung di dalamnya. Banyak sekali ayat Al-Qur'an (ayat kauniyah) yang berhubungan dengan bidang IPA (Astronomi, biologi, fisika dan kimia) dan penafsiran ayat-ayat tersebut membutuhkan iptek. Ini besar sekali pengaruhnya terhadap pembinaan imtaq peserta didik, karena dengan iptek membuktikan kalau Al-Qur'an tersebut benar-benar firman dari Allah SWT. Jadi, dengan mempelajari IAD (Iptek) bisa menambah nilai ketaqwaan kepada Sang Pencipta, karena materi IAD memperlihatkan keteraturan alam yang merupakan bukti ke Esaan Allah.

Dedi Supriadi. 2004. Membangun Bangsa Melalui Pendidikan. Remaja Rosda Karya. Bandung.

Dit. Jen. Dikti, Depdiknas, 2001, Ilmu Alamiah Dasar, Jakarta.

Dit.Jen.Dikti, Depdiknas, 2004, Modul Acuan Proses Pembelajaran Matakuliah Berkehidupan Bermasyarakat: Ilmu Sosial dan Budaya Dasar \& Ilmu Alamiah Dasar, Jakarta

Departemen Pendidikan dan Kebudayaan RI. Direktorat Jendral Pendidikan Dasar dan Menengah (1996). Naskah Keterkaitan 10 Mata Pelajaran di SMU dengan Imtaq. Jakarta, Bagian Proyek 
Peningkatan Wawasan Kependidikan Guru agama. Jakarta

Harun Yahya, 2000. Menyingkap Rahasia Alam Semesta. http:// www.geocities.com/pakdenono. Diakses Juni 2007.

Hamka. 1987. Pelajaran Agama Islam. Cet. Ke 9. Bulan Bintang. Jakarta

Keputusan Menteri Pendidikan Nasional Republik Indonesia Nomor 232/ U12090 tentang Pedoman Penyusunan Kurikulurn Pendidikan Tinggi dan Penilaian Hasil Belajar

Keputusan Menteri Pendidikan Nasional Republik Indonesia Nomor 0451U/2002 tentang Kurikulurn Inti Perguruan Tinggi

Keputusan Direktorat Jendral Pendidikan tinggi, Depcliknas Nomor 30/ DIKT1/Kep/2003 tentang Rambu-rambu Pelaksanaan Matakuliah Berkehidupan Bermasyarakat di Perguruan Tinggi

Keputusan Dir Jen Dikti, Depdiknas Nomor 44/DIKT1/Kep/2006 tentang Rambu-rambu Pelaksanaan

Indeks imtaq, 20, 163, 165, 166, 167, 168, 170, 171,172

integrasi, 20, 163
Kelompok Matakuliah Berkehidupan Bermasyarakat di Perguruan Tinggi

Milya Sari. 2004. Reorientasi Pendidikan Sains pada Lembaga Pendidikan Islam. Al-Ta'lim. Vol. XI No 16. th 2004. IAIN Imam Bonjol Padang.

Syaifuddin Sabda. 2006. Model Kurikulum Terpadu Iptek dan Imtaq, Desain, Pengembangan dan Implementasi. Quantum Teaching. Jakarta.

Tim Penulisan Buku Sains, 1981. Zat dan Energi, Buku Pelajaran Ilmu Alam untuk SMP kelas 1. Departemen Pendidikan dan Kebudayaan. Balai Pustaka.

Yusuf Qardawi, 2006. Fiqih Prioritas. http://www.geocities.com/pakdeno no. Diakses Juni 2007

Zainuddin Sardar (1996). Jihad intelektual, Merumuskan ParamiterParamiter Sains Islam, Terjemahan AE Priyono, Risalah Gusti, Surabaya.

iptek, 20, 163, 165, 166, 167, 168, 170, 171,172 